\title{
APLIKASI TEORI KATHARINE KOLBACA PADA KASUS KANKER KOLON PASCA LAPARATOMI DENGAN MUSIK
}

\author{
Monika Rini Puspitasari ${ }^{1,2}$, Agung Waluyo ${ }^{1,2}$ \\ ${ }^{1}$ Magister Ilmu Keperawatan Medikal Bedah, ${ }^{2}$ Universitas Indonesia \\ Korespodensi penulis: morin_sari@yahoo.com
}

\begin{abstract}
Abstrak
Latar belakang: Kanker kolorektal adalah keganasan yang berasal dari jaringan kolon dan menjadi penyebab kematian kedua di seluruh dunia. Laparatomi merupakan salah jenis operasi yang paling sering dilakukan. Rasa nyeri dapat muncul pasca tindakan laparatomi akibat terputusnya jaringan tubuh..

Tujuan: Penulisan studi kasus ini untuk mengidentifikasi penggunaan terapi musik dalam intervensi menurunkan rasa nyeri pasca operasi laparatomi pada kasus Tn.S.

Metode: Penilaian skala nyeri menggunakan NRS (Numeric Rate Scale) sedangkan kondisi pasien melalui observasi dan pemberian intervensi.

Hasil: Hasil observasi ditemukan data jika Tn.S mengatakan nyeri saat beraktifitas pada bagian bekas sayatan operasi laparatomi di abdomen dengan skala NRS 6. Diagnosa keperawatan utama pada kasus Tn.S adalah nyeri. Pemberian intervensi yang diberikan menggunakan pendekatan berdasarkan teori keperawatan Katharine Kolbaca yaitu teori comfort. Manajemen untuk mengatasi nyeri dapat dilakukan dengan terapi farmakologi dan non farmakologi. Terapi non farmakologi yang diberikan padaTn.S berupa terapi musik yang dipilih secara mandiri oleh $\mathrm{Tn}$.S dan dilakukan sebanyak 4 sesi dalam 2 hari.

Simpulan: Temuan dari penelitian ini adalah pemberian terapi musik memiliki efek menurunkan skala nyeri dibandingkan pada awal pengkajian.
\end{abstract}

Kata kunci: Kanker kolon, Laparatomi, Nyeri, Terapi musik

\section{Pendahuluan}

Angka kematian terkait kanker telah meningkat hampir $40 \%$ selama 40 tahun terakhir. Diperkirakan dalam 15 tahun mendatang akan terjadi peningkatan sebanyak $60 \%$, dengan 13 juta orang diperkirakan meninggal karena kanker pada tahun 2030. Kaker kolorektal tetapi telah menjadi kanker yang dominan di negaranegara Barat, terhitung ada sekitar $10 \%$ dari kematian terkait kanker ini. Alasan yang menjelaskan peningkatan insiden ini kebiasaan makan yang buruk, merokok, aktivitas fisik yang rendah dan obesitas di negara-negara barat. Mengingat bahwa tingkat infeksi Helicobacter pylori (faktor penyebab kanker lambung) telah menurun drastis, kanker kolorektal sekarang merupakan presentasi utama dari sindrom
Lynch (jenis kanker kolorektal non-poliposis herediter), sedangkan pembawa sindrom ini dulu didominasi oleh kanker lambung (Kuipers et al., 2015).

Menurut American Cancer Society, kanker kolon yang merupakan bagian dari kanker kolorektal (KKR) adalah kanker ketiga terbanyak dan merupakan kanker penyebab kematian ketiga terbanyak pada pria dan wanita di Amerika Serikat (Society AC, 2017). Meningkatnya angka kejadian kanker kolon dipengaruhi oleh lingkungan dan gaya hidup. Pola diet mempunyai peranan penting dan dapat menjadikan penyebab terjadinya kanker kolon dan rektum. Tingkat konsumsi makanan redah serat yang rendah serta tingginya konsumsi protein hewani dan lemak merupakan faktor 
penyebab terjadinya kanker kolon (Desen, 2013).

Menurut data GLOBOCAN 2018, kanker kolorektal (CRC) adalah kanker paling mematikan ketiga dan keempat yang paling sering didiagnosis di dunia. Hampir 2 juta kasus baru dan sekitar 1 juta kematian diperkirakan terjadi pada tahun 2018. Insiden CRC terus meningkat di seluruh dunia, terutama di negara berkembang yang mengadopsi cara hidup "barat". Obesitas, gaya hidup yang tidak banyak bergerak, konsumsi daging merah, alkohol, dan tembakau dianggap sebagai faktor pendorong di balik meningkatnya angka kejadian CRC. Namun, kemajuan terbaru dalam skrining deteksi dini dan pilihan pengobatan telah mengurangi mortalitas CRC di negara maju, bahkan dalam menghadapi peningkatan insiden. Pengujian genetik dan mengkaji riwayat keluarga dapat memungkinkan mereka yang memiliki kecenderungan turuntemurun terhadap neoplasma untuk mengambil tindakan pencegahan. Sementara itu, masyarakat umum dapat mengurangi risiko dengan mengurangi konsumsi daging merah, alkohol, dan tembakau serta meningkatkan konsumsi serat, makanan sehat, serta vitamin dan mineral tertentu (Rawla, Sunkara, \& Barsouk, 2019).

Kanker kolorektal adalah kanker paling umum ketiga dan penyebab kematian kedua di seluruh dunia. Faktor risiko yang diketahui adalah sebagai berikut: usia, jenis kelamin pria, merokok, obesitas, diet rendah serat, resistensi insulin, dan sindrom metabolik (Rawla et al., 2019). Kematian akibat kanker kolon di Amerika mencapai 11\%, dengan insiden lebih tinggi terjadi pada laki-laki. Faktor umur mempengaruhi kejadian kanker kolon, insiden kanker kolon meningkat di atas umur 50 tahun. Banyak faktor yang berperan terhadap kejadian kanker kolon seperti konsumsi alkohol, merokok, dan gaya hidup pasif juga termasuk faktor yang berperan. Deteksi awal melalui rutin skrining adalah kunci dari menurunnya mortalitas kanker kolon (Black, 2014).

Tindakan yang umum dilakukan pada kasus kanker kolon adalah laparatomi.
Laparatomi merupakan tindakan pembedahan yang dilakukan dibagian garis tegah abdomen sepanjang linea alba ke bagian rongga peritoneum. Indikasi dilakukannya tindakan laparatomi umumnya pada kasus digestif dan kandungan seperti kanker kolon dan rektum serta hernia ingunialis. Komplikasi yang terjadi pasca pembedahan antara lain pendarahan, infeksi, hematoma dan nyeri (Rajaretnam N, Okoye E, Burns B, 2020).

Nyeri merupakan salah satu efek samping dari pembedahan laparatomi. Nyeri menurut International Association for the Study of Pain (IASP) merupakan pengalaman sensoris dan emosional yang tidak menyenangkan berhubungan dengan kerusakan jaringan aktual atau potensial. atau dijelaskan dalam istilah kerusakan tersebut (Treede, 2018).

Penanganan nyeri pasca operasi membutuhkan penatalaksanaan yang tepat. Efek dari nyeri yang tidak tertangani dapat menyebabkan terjadinya gangguan pada sistem kardiovaskular (meningkatnya detak jantung, tekanan darah dan kebutuhan oksigen), pernafasan (meningkatnya laju pernafasan), imun (rentan terjadinya infeksi) dan sistem tubuh lainnya (Swift, 2018). Penatalaksanaan untuk mengatasi nyeri pasca operasi dapat dilakukan melalui managemen farmakologi dan non farmakologi. Pemberian farmakologi dapat menggunakan penanganan nyeri dari WHO yang terdiri dari tahap penggunaan analgesik sederhana (misal penggunaan Paracetamol), penggunaan opoid golongan sedang (misal penggunaan Codein ditambah penggunaan Paracetamol) dan penggunaan opoid golongan kuat (misal penggunaan Morphine ditambahkan dengan penggunaan Paracetamol).

Penatalaksanaan non farmakologi dapat diberikan untuk mengurangi rasa nyeri dengan resiko yang rendah. Banyak terapi non farmakologi yang dapat dilakukan contohnya penggunaan aroma terapi, pemberian accupressure dan terapi musik. Berdasarkan penelitian, terapi musik memiliki efek untuk mengurangi nyeri. 
Penulisan ini bertujuan untuk menggambarkan aplikasi penerapan teori Katharine Kolbaca yaitu teori comfort pada kasus pasien dengan kanker kolon pasca operasi laparatomi. Rasa nyeri yang dirasakan diharapkan berkurang dan dapat meningkatkan kualitas hidup pasien pasca operasi.

\section{Metode Penelitian}

Metode yang dilakukan yaitu dengan memberikan rencana pengelolaan berupa asuhan keperawatan yang dilakukukan secara mandiri, pemberian terapi komplementer dan kolaboratif dengan tim kesehatan lainnya pada Tn.J. Teknik pengumpulan data dilakukan dengan menggunakan teknik metodologI keperawatan dimulai dari pengkajian, analisa data, intervensi komplementer dan kolaboratif.

Penilaian nyeri yang digunakan pada kasus Tn.J adalah Numeric Rating Scale (NRS). Pasien diminta untuk melingkari atau memilih angka sesuai dengan rasa nyeri yang dirasakan. Skala yang digunakan dengan skala Likert 11 poin, dengan nilai 0 hingga 10.

\section{Hasil dan Pembahasan Ilustrasi Kasus}

Studi kasus ini dilakukan diruang perawatan pada pasien Tn.S berusia 40 tahun dengan diagnosa kanker kolon stadium III. Pasien dirawat di rumah sakit karena menjalani proses operasi laparatomi dan pembuatan stoma. Pasien sebelum dirawat mengalami keluhan penurunan berat badan dalam 3 bulan terakhir dan adanya kesulitan saat buang air besar (BAB). Berdasarkan hasil anamesa, pasien lebih menyukai makanan fast food dan sedikit mengkonsumsi sayuran sejak kecil. Pasien dirawat sejak 09 September 2020 dan dilakukan tindakan operasi pada 10 September 2020. Kesadaran alert, terpasang NGT, TD 130/80 mmHg, N 96x/mnt, P 20x/mnt, S $36,3^{\circ} \mathrm{C}$. Tampak pada bagian abdomen luka operasi.

\section{Pengkajian}

Pengkajian pada Tn.J dilakukan dengan tehnik autoanamnesa. Dari pengkajian didapatkan data subjektif : Klien mengatakan tidak nafsu makan, ada rasa mual jika diisi, adanya penurunan berat badan $20 \mathrm{Kg}$ dalam 3 bulan. Klien mengatakan nyeri $P$ (provocate): Klien mengatakan merasa nyeri di perut, Q (quality) : Seperti ditusuk-tusuk, $\mathrm{R}$ : Abdomen, $\mathrm{S}$ (scale) : 6 (sedang), $\mathrm{T}$ (time) : nyeri dirasakan hilang timbul $\pm 3-5 \mathrm{~cm}$. Klien mengatakan belum mengetahui cara sholat jika terpasang stoma dan merasa tidak layak untuk sholat karena saat sholat, feses dapat keluar secara tiba-tiba.

Data objektif yang ditemukan saat pengkajian diantaranya TB : $165 \mathrm{~cm}, \mathrm{BB}$ : $48 \mathrm{Kg}$, BMI : 16,0 kg/m² (Berat Badan Kurang), GDS : $89 \mathrm{mg} / \mathrm{dl}$. Hasil lab : Protein total $5,4 \mathrm{~g} / \mathrm{dL}$, Albumin $2,9 \mathrm{~g} / \mathrm{dL}$, Globulin $2,5 \mathrm{~g} / \mathrm{dL}$, Hemoglobin 10,1 gr\%, Leukosit 14,25 . Diet saat di RS : diet cair (susu) 6x100 cc via NGT. Infus : Clinimix $1000 \mathrm{cc} / 24$ jam dan $\mathrm{NaCl} \quad 0,9 \% \quad 500 \mathrm{cc} / 12$ jam. Pengeluaran feses atau BAB melaui stoma. End stoma terdapat pada region left lumbal, feses berbentuk cair, warna coklat tua, produksi BAB $2-3$ kali sehari.Klien belum mampu membersihkan stoma dan katung stomanya sendiri,terdapat luka jahitan dari daerah gaster hingga umbilikus $( \pm 10 \mathrm{~cm})$ dengan stapler, terdapat kolostomy pada regio left lumbal. Klien tampak meringis dan memegangi area luka post op saat berubah posisi, terdapat nyeri tekan di ke 4 kuadran abdomen dan klien menanyakan tata cara sholat orang dengan stoma.

\section{Diagnosa Keperawatan}

Diagnosa keperawatan yang muncul dari data pengkajian menggunakan 14 kebutuhan Virginia Henderson adalah nyeri akut, ketidakseimbangan nutrisi kurang dari kebutuhan tubuh, gangguan citra tubuh, kerusakan intergritas kulit, resiko infeksi dan definisi pengetahuan. Diagnosa utama pada kasus Tn. J yaitu nyeri akut. Nyeri akut merupakan pengalaman dan emosional berhubungan dengan kerusakan jaringan aktual atu fungsional dengan intensitas 
ringan hingga berat yang berlangsung kurang dari 3 bulan. Penyebab nyeri akut antara lain terjadinya cidera fisiologis (adanya proses inflamasi, iskemi dan neoplasma) cidera kimiawi (terkena bahan kimiawi) dan cidera fisik (proses pembedahan, ansees dan trauma) (Tim Pokja SDKI PPNI,2017).

\section{Intervensi}

Intervensi keperawatan yang dibuat berdasarkan dignosa utama yaitu nyeri, berdasarkan teori NIC dan NOC. Berdasarkan NIC dan NOC, intervensi keperawatan yang dilakukan berfungsi untuk menghilangkan, mengurangi dan mencegah munculnya masalah baru pada pasien kriteria hasil yang diharapkan setelah dilakukan intervensi manajemen nyeri pasien menyatakan nyeri berkurang, tidak tampak kesakitan atau menahan nyeri dan pasien nyeri menyatakan jika nyeri terkontrol(Butcher, Bulechek, Dochterman, \& Wagner, 2018).

Rencana tindakan yang dapat dilakukan pada manajemen nyeri akut dapat berupa tindakan mandiri, kolaborasi, penggunaaan terapi farmakologi dan non farmakologi. Tindakan mandiri diantaranya berupa pengkajian nyeri secara komprehensif (lokasi, karakteristik, onset, frekuensi, kualitas, intensitas dan faktor pemicu). Penanganan nyeri melalui kolaborasi dengan dokter yaitu dengan pemberian terapi farmakologi berupa analgetik untuk mengurangi nyeri. Terapi non farmakologi yang dapat dilakukan pada pasien nyeri pasca operasi laparatomi diantaranya pemberian terapi musik, akupresure pada titik-titik tertentu, penggunaan jarum akupuntur, guide imagery dan aromaterapi.

Penanganan nyeri yang tidak optimal akan menyebabkan berbagai permasalahan pada pasien biologis, psikologi, sosial dan kualitas hidup. Injuri, trauma, infeksi dan kerusakan saraf hingga masalah psikologis seperti cemas, gangguan tidur dan depresi terjadi saat nyeri tidak tertangani. Kualitas hidup dalam melakukan aktivitas harian, kesehatan mental serta fungsi keluarga dan sosial menjadi faktor kesehatan yang dapat mengganggu kualitas hidup pasien (Dueñas, Ojeda, Salazar, Mico, \& Failde2, 2016).

\section{Pembahasan}

Asuhan keperawatan yang dilakukan pada kasus Tn.S dalam penulisan ini menggunakan pendekatan teori keperawatan yang dikembangkan oleh Katharine Kolbaca yaitu teori comfort. Teori comfort memiliki konsep utama yaitu menilai kenyamanan dengan membuat struktur taksonomi yang bersumber pada tiga tipe kenyamanan dan menghubungkan ketiga tiper kenyamanan tersebut dengan empat pengalaman kenyamanan (Smith \& Parker, 2015).

Keluhan nyeri pada pasien kanker kolon pasca operasi laparatomi merupakan masalah keperawatan yang sering ditemukan. Rasa nyeri yang dialami Tn.S merupakan suatu bentuk pengalaman sensori dan emosional yang tidak menyenangkan akibat adanya kerusakan jaringan pada bagian abdomen pasca tindakan operasi laparatomi. Mekanisme nyeri dimulai dengan adanya kerusakan jaringan yang terus berkembang akan memicu pelepasan zat-zat kimia seperti prostaglandin E, bradikinin, serotinin dan histamin. Zat kima tersebut akan merangsang reseptor nyeri dan mentransmisikan medula spinalis dan selanjutnya menuju talamus, kemudian di kortek serebri nyeri tersebut dipersepsikan (Petel, 2010).

Dalam mengatasi nyeri pada Tn.S, intervensi keperawatan yang dilakukan adalah pain management yang mengacu pada NIC. Dengan melakukan intervensi pain management diharapkan Tn.S dapat mengontrol nyeri pada skala 4 dengan kriteria hasil mampu mengenal penyebab nyeri, gejala nyeri yang dirasakan dan waktu timbulnya nyeri, tanda vital dalam batas normal, mampu menggunakan terapi farmakologi serta non farmakologi dan melaporkan terjadinya penurunan skala nyeri (Butcher et al., 2018).

Manajemen nyeri yang baik setelah operasi menurut program Enhanced Recovery After Surgery (ERAS) dianjurkan agar pasien dapat melakukan mobilisasi sesegera mungkin, menurunkan resiko komplikasi, 
memperpendek lama rawat dan mengurangi terjadinya angka kematian. Penatalaksanaan manajemen nyeri yang tidak adekuat dapat menyebabkan lamanya proses penyembuhan luka, tromboemboli vena dan infeksi sistemik (Scott, Nygren, \& Francis, 2019). Hal ini tentu juga pada kasus pasien pasca pembedahan laparatomi.

Manajemen untuk mengurangi rasa nyeri dapat menggunakan metode farmakologi dan non farmakologi. Kolaborasi dalam pemberian analgesik umum diberikan sejak pasien pasien menyelesaikan tindakan operasi. Perawat memiliki peran untuk mengkaji nyeri secara komprehensif dan memantau efektivitas pemberian terapi analgetik. Pengunaan obat-obatan analgetik yang diberikan berasal dari golongan opoid untuk nyeri dengan skala tinggi dan dan golongan non opid untuk rasa nyeri ringan hingga sedang.

Terapi komplementer dapat diberikan untuk mengurangi nyeri tanpa mengganggu terapi lainnya. Terapi musik salah satu jenis terapi komplementer yang banyak digunakan untuk menangani masalah nyeri. Terapi musik bertujuan untuk menenangkan pasien secara emosional sehingga sekresi adrenalin akan terhambat dan sebaliknya sekresi kortisol akan meningkat sehingga efek nyeri menjadi berkurang. Pemberian terapi musik juga dapat mempengaruhi hormon stres dan meningkatkan aktivitas dopamin pada mesolimbik otak (Singh \& Chaturvedi, 2015). Terapi musik merupakan intervensi non farmakologi yang aman, mudah dilakukan dalam praktik keperawatan.

Pemberian terapi musik merupakan bentuk dari rangsang yang diterima oleh indera pendengaran yang mempengaruhi kebutuhan secara fisik, psikologi, keognitif, sosial dan spiritual pendengarnya (Lindquist, Ruth; Tracy, Mary Fran; Snyder, 2018 ; Sykes, Nigel; Michael Bennet, 2008). Musik memiliki berbagai faktor yang mampu mengaktifkan otak secara bilateral didalam ritme, melodi, harmoni, timbre, akord serta dinamika musik (Singh \& Chaturvedi, 2015).

Pemberian terapi musik pada beberapa penelitian menunjukkan memiliki efektifitas untuk menurukan intensitas dan nyeri. Penelitian tentang pemberian terapi musik pada kasus pasien pasca operasi abdomen memiliki hasil penggunaan menurunkan intensitas dan distress nyeri pada hari kedua (Vaajoki, Pietilä, Kankkunen, \& Vehviläinen-Julkunen, 2013).

Tn.S setelah diberikan kombinasi terapi farmakologi dan non farmakologi berupa terapi musik sebanyak empat kali selama 2 hari terdapat penurunan skala nyeri secara bertahap. Penurunan skala nyeri pada pasien Tn.S dirasakan mulai pada pemberian terapi musik dipertemuan kedua. Pada pertemuan pertama setelah diberikan terapi musik memiliki skala nyeri Tn.S berdasarkan NRS bernilai 6, pemberian terapi belum menunjukkan terjadinya penurunan skala nyeri karena pasien belum dapat memfokuskan dirinya pada terapi musik yang diberikan. Penelitian yaitu dalam pemberian terapi musik dapat menurunkan tingkat nyeri di hari kedua pada pasien pasca pasien operasi abdomen. Saat dilakukan evaluasi sesi ke 4, diketahui jika skala nyeri Tn.S berada pada nilai NRS 3 .

Hasil pemberian intervensi berdasarkan teori comfort dari Katherine Kolbaca diketahui jika terapi non farmakologi berupa terapi musik dapat menurunkan rasa nyeri pada kasus kanker kolon pasca operasi laparatomi. Penggunaan terapi musik mendukung efektifitas terapi farmakologi dan mudah dilakukan dalam manajemen nyeri sehingga kenyamanan didapatkan oleh pasien.

\section{Simpulan}

Perawat penting untuk melakukan pengkajian nyeri pasca tindakan operasi laparatomi. Pengkajian nyeri yang efektif harus dilakukan secara komprehensif untuk menentukan intervensi yang perlu dilakukan. Penggunaan terapi non farmakologis dapat digunakan sebagai terapi tambahan atau pendamping dari pemberian terapi farmakologis. Dalam beberapa penelitian, penggunaan terapi musik diketahui memiliki efek bukan hanya untuk menurunkan tingkat nyeri tetapi juga menurunkan distresss pasien 
pasca tindakan operasi. Penggunaan terapi musik merupakan bagian dari asuhan keperawatan.

\section{Referensi}

Black, J. M \& Hawk, J. H (2014). Keperawatan medikal bedah, manajemen klinis untuk hasil yang diharapkan. Edisi 8. Buku 2. Singapore Pte Ltd: Elsevier

Butcher, H. K., Bulechek, G. M., Dochterman, J. M., \& Wagner, C. M. (2018). Nursing Interventions Classification ( NIC) (Seventh Ed). Elsevier Inc.

Dueñas, M., Ojeda, B., Salazar, A., Mico, J. A., \& Failde2, I. (2016). A review of chronic pain impact on patients, their social environment and the health care system. Journal of pain research, (9), 457-467.

https://doi.org/https://doi.org/10.2147/ JPR.S105892

Kuipers, E. J., Grady, W. M., Lieberman, D., Seufferlein, T., Sung, J. J., Boelens, P. G., ... Watanabe, T. (2015). Colorectal cancer. Nature Publishing Group, https://doi.org/10.1038/nrdp.2015.65

Lindquist, Ruth; Tracy, Mary Fran; Snyder, M. (2018). Complementary and Alternative Therapies in Nursing (Eighth edi). New York, NY: Springer Publishing Company.

Rawla, P., Sunkara, T., \& Barsouk, A. (2019). Epidemiology of colorectal cancer: incidence, mortality , survival , and risk factors. Gastroenterology Rev, 14, 89-103. https://doi.org/DOI:

https://doi.org/10.5114/pg.2018.81072

Scott, U. O. G. M. J., Nygren, M. H. J., \& Francis, N. D. N. (2019). Guidelines for Perioperative Care in Elective Colorectal Surgery: Enhanced Recovery After Surgery ( ERAS) Society Recommendations: 2018. World Journal of Surgery, 43(3), 659-695.

https://doi.org/10.1007/s00268-018- 4844-y

Singh, P., \& Chaturvedi, A. (2015).

Complementary and Alternative

Medicine in Cancer Pain

Management: A Systematic Review.

21(1),

105-115.

https://doi.org/10.4103/0973-

1075.150202

Smith, M. C., \& Parker, M. E. (2015).

Nursing Theories \& Nursing Practice (Fourth Edi). Philadelphia,: F. A. Davis Company.

Swift, A. (2018). Understanding the effect of pain and how the human body responds. NurisingTimes, 22-26.

Sykes, Nigel; Michael Bennet, C. Y. (2008). Clinical Pain Management: Cancer Pain 2nd edition (2nd editio; A. S. Rice, ed.). Hodder Arnold.

Treede, R. (2018). The International Association for the Study of Pain definition of pain : as valid in 2018 as in 1979 , but in need of regularly updated footnotes. Pain reports, 3, 35.

https://doi.org/doi:10.1097/PR9.0000 000000000643

Vaajoki, A., Pietilä, A. M., Kankkunen, P., \& Vehviläinen-Julkunen, K. (2013). Music intervention study in abdominal surgery patients: Challenges of an intervention study in clinical practice. International Journal of Nursing Practice, 19(2), 206-213.

https://doi.org/10.1111/ijn.12052 


\title{
APLIKASI TEORI KATHARINE KOLBACA PADA KASUS KANKER KOLON PASCA LAPARATOMI DENGAN MUSIK
}

\author{
Monika Rini Puspitasari ${ }^{1,2}$, Agung Waluyo ${ }^{1,2}$ \\ ${ }^{1}$ Magister Ilmu Keperawatan Medikal Bedah, ${ }^{2}$ Universitas Indonesia \\ Korespodensi penulis: morin_sari@yahoo.com
}

\begin{abstract}
Abstrak
Latar belakang: Kanker kolorektal adalah keganasan yang berasal dari jaringan kolon dan menjadi penyebab kematian kedua di seluruh dunia. Laparatomi merupakan salah jenis operasi yang paling sering dilakukan. Rasa nyeri dapat muncul pasca tindakan laparatomi akibat terputusnya jaringan tubuh..

Tujuan: Penulisan studi kasus ini untuk mengidentifikasi penggunaan terapi musik dalam intervensi menurunkan rasa nyeri pasca operasi laparatomi pada kasus Tn.S.

Metode: Penilaian skala nyeri menggunakan NRS (Numeric Rate Scale) sedangkan kondisi pasien melalui observasi dan pemberian intervensi.

Hasil: Hasil observasi ditemukan data jika Tn.S mengatakan nyeri saat beraktifitas pada bagian bekas sayatan operasi laparatomi di abdomen dengan skala NRS 6. Diagnosa keperawatan utama pada kasus Tn.S adalah nyeri. Pemberian intervensi yang diberikan menggunakan pendekatan berdasarkan teori keperawatan Katharine Kolbaca yaitu teori comfort. Manajemen untuk mengatasi nyeri dapat dilakukan dengan terapi farmakologi dan non farmakologi. Terapi non farmakologi yang diberikan padaTn.S berupa terapi musik yang dipilih secara mandiri oleh $\mathrm{Tn}$.S dan dilakukan sebanyak 4 sesi dalam 2 hari.

Simpulan: Temuan dari penelitian ini adalah pemberian terapi musik memiliki efek menurunkan skala nyeri dibandingkan pada awal pengkajian.
\end{abstract}

Kata kunci: Kanker kolon, Laparatomi, Nyeri, Terapi musik

\section{Pendahuluan}

Angka kematian terkait kanker telah meningkat hampir $40 \%$ selama 40 tahun terakhir. Diperkirakan dalam 15 tahun mendatang akan terjadi peningkatan sebanyak $60 \%$, dengan 13 juta orang diperkirakan meninggal karena kanker pada tahun 2030. Kaker kolorektal tetapi telah menjadi kanker yang dominan di negaranegara Barat, terhitung ada sekitar $10 \%$ dari kematian terkait kanker ini. Alasan yang menjelaskan peningkatan insiden ini kebiasaan makan yang buruk, merokok, aktivitas fisik yang rendah dan obesitas di negara-negara barat. Mengingat bahwa tingkat infeksi Helicobacter pylori (faktor penyebab kanker lambung) telah menurun drastis, kanker kolorektal sekarang merupakan presentasi utama dari sindrom
Lynch (jenis kanker kolorektal non-poliposis herediter), sedangkan pembawa sindrom ini dulu didominasi oleh kanker lambung (Kuipers et al., 2015).

Menurut American Cancer Society, kanker kolon yang merupakan bagian dari kanker kolorektal (KKR) adalah kanker ketiga terbanyak dan merupakan kanker penyebab kematian ketiga terbanyak pada pria dan wanita di Amerika Serikat (Society AC, 2017). Meningkatnya angka kejadian kanker kolon dipengaruhi oleh lingkungan dan gaya hidup. Pola diet mempunyai peranan penting dan dapat menjadikan penyebab terjadinya kanker kolon dan rektum. Tingkat konsumsi makanan redah serat yang rendah serta tingginya konsumsi protein hewani dan lemak merupakan faktor 
penyebab terjadinya kanker kolon (Desen, 2013).

Menurut data GLOBOCAN 2018, kanker kolorektal (CRC) adalah kanker paling mematikan ketiga dan keempat yang paling sering didiagnosis di dunia. Hampir 2 juta kasus baru dan sekitar 1 juta kematian diperkirakan terjadi pada tahun 2018. Insiden CRC terus meningkat di seluruh dunia, terutama di negara berkembang yang mengadopsi cara hidup "barat". Obesitas, gaya hidup yang tidak banyak bergerak, konsumsi daging merah, alkohol, dan tembakau dianggap sebagai faktor pendorong di balik meningkatnya angka kejadian CRC. Namun, kemajuan terbaru dalam skrining deteksi dini dan pilihan pengobatan telah mengurangi mortalitas CRC di negara maju, bahkan dalam menghadapi peningkatan insiden. Pengujian genetik dan mengkaji riwayat keluarga dapat memungkinkan mereka yang memiliki kecenderungan turuntemurun terhadap neoplasma untuk mengambil tindakan pencegahan. Sementara itu, masyarakat umum dapat mengurangi risiko dengan mengurangi konsumsi daging merah, alkohol, dan tembakau serta meningkatkan konsumsi serat, makanan sehat, serta vitamin dan mineral tertentu (Rawla, Sunkara, \& Barsouk, 2019).

Kanker kolorektal adalah kanker paling umum ketiga dan penyebab kematian kedua di seluruh dunia. Faktor risiko yang diketahui adalah sebagai berikut: usia, jenis kelamin pria, merokok, obesitas, diet rendah serat, resistensi insulin, dan sindrom metabolik (Rawla et al., 2019). Kematian akibat kanker kolon di Amerika mencapai 11\%, dengan insiden lebih tinggi terjadi pada laki-laki. Faktor umur mempengaruhi kejadian kanker kolon, insiden kanker kolon meningkat di atas umur 50 tahun. Banyak faktor yang berperan terhadap kejadian kanker kolon seperti konsumsi alkohol, merokok, dan gaya hidup pasif juga termasuk faktor yang berperan. Deteksi awal melalui rutin skrining adalah kunci dari menurunnya mortalitas kanker kolon (Black, 2014).

Tindakan yang umum dilakukan pada kasus kanker kolon adalah laparatomi.
Laparatomi merupakan tindakan pembedahan yang dilakukan dibagian garis tegah abdomen sepanjang linea alba ke bagian rongga peritoneum. Indikasi dilakukannya tindakan laparatomi umumnya pada kasus digestif dan kandungan seperti kanker kolon dan rektum serta hernia ingunialis. Komplikasi yang terjadi pasca pembedahan antara lain pendarahan, infeksi, hematoma dan nyeri (Rajaretnam N, Okoye E, Burns B, 2020).

Nyeri merupakan salah satu efek samping dari pembedahan laparatomi. Nyeri menurut International Association for the Study of Pain (IASP) merupakan pengalaman sensoris dan emosional yang tidak menyenangkan berhubungan dengan kerusakan jaringan aktual atau potensial. atau dijelaskan dalam istilah kerusakan tersebut (Treede, 2018).

Penanganan nyeri pasca operasi membutuhkan penatalaksanaan yang tepat. Efek dari nyeri yang tidak tertangani dapat menyebabkan terjadinya gangguan pada sistem kardiovaskular (meningkatnya detak jantung, tekanan darah dan kebutuhan oksigen), pernafasan (meningkatnya laju pernafasan), imun (rentan terjadinya infeksi) dan sistem tubuh lainnya (Swift, 2018). Penatalaksanaan untuk mengatasi nyeri pasca operasi dapat dilakukan melalui managemen farmakologi dan non farmakologi. Pemberian farmakologi dapat menggunakan penanganan nyeri dari WHO yang terdiri dari tahap penggunaan analgesik sederhana (misal penggunaan Paracetamol), penggunaan opoid golongan sedang (misal penggunaan Codein ditambah penggunaan Paracetamol) dan penggunaan opoid golongan kuat (misal penggunaan Morphine ditambahkan dengan penggunaan Paracetamol).

Penatalaksanaan non farmakologi dapat diberikan untuk mengurangi rasa nyeri dengan resiko yang rendah. Banyak terapi non farmakologi yang dapat dilakukan contohnya penggunaan aroma terapi, pemberian accupressure dan terapi musik. Berdasarkan penelitian, terapi musik memiliki efek untuk mengurangi nyeri. 
Penulisan ini bertujuan untuk menggambarkan aplikasi penerapan teori Katharine Kolbaca yaitu teori comfort pada kasus pasien dengan kanker kolon pasca operasi laparatomi. Rasa nyeri yang dirasakan diharapkan berkurang dan dapat meningkatkan kualitas hidup pasien pasca operasi.

\section{Metode Penelitian}

Metode yang dilakukan yaitu dengan memberikan rencana pengelolaan berupa asuhan keperawatan yang dilakukukan secara mandiri, pemberian terapi komplementer dan kolaboratif dengan tim kesehatan lainnya pada Tn.J. Teknik pengumpulan data dilakukan dengan menggunakan teknik metodologI keperawatan dimulai dari pengkajian, analisa data, intervensi komplementer dan kolaboratif.

Penilaian nyeri yang digunakan pada kasus Tn.J adalah Numeric Rating Scale (NRS). Pasien diminta untuk melingkari atau memilih angka sesuai dengan rasa nyeri yang dirasakan. Skala yang digunakan dengan skala Likert 11 poin, dengan nilai 0 hingga 10.

\section{Hasil dan Pembahasan Ilustrasi Kasus}

Studi kasus ini dilakukan diruang perawatan pada pasien Tn.S berusia 40 tahun dengan diagnosa kanker kolon stadium III. Pasien dirawat di rumah sakit karena menjalani proses operasi laparatomi dan pembuatan stoma. Pasien sebelum dirawat mengalami keluhan penurunan berat badan dalam 3 bulan terakhir dan adanya kesulitan saat buang air besar (BAB). Berdasarkan hasil anamesa, pasien lebih menyukai makanan fast food dan sedikit mengkonsumsi sayuran sejak kecil. Pasien dirawat sejak 09 September 2020 dan dilakukan tindakan operasi pada 10 September 2020. Kesadaran alert, terpasang NGT, TD 130/80 mmHg, N 96x/mnt, P 20x/mnt, S $36,3^{\circ} \mathrm{C}$. Tampak pada bagian abdomen luka operasi.

\section{Pengkajian}

Pengkajian pada Tn.J dilakukan dengan tehnik autoanamnesa. Dari pengkajian didapatkan data subjektif : Klien mengatakan tidak nafsu makan, ada rasa mual jika diisi, adanya penurunan berat badan $20 \mathrm{Kg}$ dalam 3 bulan. Klien mengatakan nyeri $P$ (provocate): Klien mengatakan merasa nyeri di perut, Q (quality) : Seperti ditusuk-tusuk, $\mathrm{R}$ : Abdomen, $\mathrm{S}$ (scale) : 6 (sedang), $\mathrm{T}$ (time) : nyeri dirasakan hilang timbul $\pm 3-5 \mathrm{~cm}$. Klien mengatakan belum mengetahui cara sholat jika terpasang stoma dan merasa tidak layak untuk sholat karena saat sholat, feses dapat keluar secara tiba-tiba.

Data objektif yang ditemukan saat pengkajian diantaranya TB : $165 \mathrm{~cm}, \mathrm{BB}$ : $48 \mathrm{Kg}$, BMI : 16,0 kg/m² (Berat Badan Kurang), GDS : $89 \mathrm{mg} / \mathrm{dl}$. Hasil lab : Protein total $5,4 \mathrm{~g} / \mathrm{dL}$, Albumin $2,9 \mathrm{~g} / \mathrm{dL}$, Globulin $2,5 \mathrm{~g} / \mathrm{dL}$, Hemoglobin 10,1 gr\%, Leukosit 14,25 . Diet saat di RS : diet cair (susu) 6x100 cc via NGT. Infus : Clinimix $1000 \mathrm{cc} / 24$ jam dan $\mathrm{NaCl} \quad 0,9 \% \quad 500 \mathrm{cc} / 12$ jam. Pengeluaran feses atau BAB melaui stoma. End stoma terdapat pada region left lumbal, feses berbentuk cair, warna coklat tua, produksi BAB $2-3$ kali sehari.Klien belum mampu membersihkan stoma dan katung stomanya sendiri,terdapat luka jahitan dari daerah gaster hingga umbilikus $( \pm 10 \mathrm{~cm})$ dengan stapler, terdapat kolostomy pada regio left lumbal. Klien tampak meringis dan memegangi area luka post op saat berubah posisi, terdapat nyeri tekan di ke 4 kuadran abdomen dan klien menanyakan tata cara sholat orang dengan stoma.

\section{Diagnosa Keperawatan}

Diagnosa keperawatan yang muncul dari data pengkajian menggunakan 14 kebutuhan Virginia Henderson adalah nyeri akut, ketidakseimbangan nutrisi kurang dari kebutuhan tubuh, gangguan citra tubuh, kerusakan intergritas kulit, resiko infeksi dan definisi pengetahuan. Diagnosa utama pada kasus Tn. J yaitu nyeri akut. Nyeri akut merupakan pengalaman dan emosional berhubungan dengan kerusakan jaringan aktual atu fungsional dengan intensitas 
ringan hingga berat yang berlangsung kurang dari 3 bulan. Penyebab nyeri akut antara lain terjadinya cidera fisiologis (adanya proses inflamasi, iskemi dan neoplasma) cidera kimiawi (terkena bahan kimiawi) dan cidera fisik (proses pembedahan, ansees dan trauma) (Tim Pokja SDKI PPNI,2017).

\section{Intervensi}

Intervensi keperawatan yang dibuat berdasarkan dignosa utama yaitu nyeri, berdasarkan teori NIC dan NOC. Berdasarkan NIC dan NOC, intervensi keperawatan yang dilakukan berfungsi untuk menghilangkan, mengurangi dan mencegah munculnya masalah baru pada pasien kriteria hasil yang diharapkan setelah dilakukan intervensi manajemen nyeri pasien menyatakan nyeri berkurang, tidak tampak kesakitan atau menahan nyeri dan pasien nyeri menyatakan jika nyeri terkontrol(Butcher, Bulechek, Dochterman, \& Wagner, 2018).

Rencana tindakan yang dapat dilakukan pada manajemen nyeri akut dapat berupa tindakan mandiri, kolaborasi, penggunaaan terapi farmakologi dan non farmakologi. Tindakan mandiri diantaranya berupa pengkajian nyeri secara komprehensif (lokasi, karakteristik, onset, frekuensi, kualitas, intensitas dan faktor pemicu). Penanganan nyeri melalui kolaborasi dengan dokter yaitu dengan pemberian terapi farmakologi berupa analgetik untuk mengurangi nyeri. Terapi non farmakologi yang dapat dilakukan pada pasien nyeri pasca operasi laparatomi diantaranya pemberian terapi musik, akupresure pada titik-titik tertentu, penggunaan jarum akupuntur, guide imagery dan aromaterapi.

Penanganan nyeri yang tidak optimal akan menyebabkan berbagai permasalahan pada pasien biologis, psikologi, sosial dan kualitas hidup. Injuri, trauma, infeksi dan kerusakan saraf hingga masalah psikologis seperti cemas, gangguan tidur dan depresi terjadi saat nyeri tidak tertangani. Kualitas hidup dalam melakukan aktivitas harian, kesehatan mental serta fungsi keluarga dan sosial menjadi faktor kesehatan yang dapat mengganggu kualitas hidup pasien (Dueñas, Ojeda, Salazar, Mico, \& Failde2, 2016).

\section{Pembahasan}

Asuhan keperawatan yang dilakukan pada kasus Tn.S dalam penulisan ini menggunakan pendekatan teori keperawatan yang dikembangkan oleh Katharine Kolbaca yaitu teori comfort. Teori comfort memiliki konsep utama yaitu menilai kenyamanan dengan membuat struktur taksonomi yang bersumber pada tiga tipe kenyamanan dan menghubungkan ketiga tiper kenyamanan tersebut dengan empat pengalaman kenyamanan (Smith \& Parker, 2015).

Keluhan nyeri pada pasien kanker kolon pasca operasi laparatomi merupakan masalah keperawatan yang sering ditemukan. Rasa nyeri yang dialami Tn.S merupakan suatu bentuk pengalaman sensori dan emosional yang tidak menyenangkan akibat adanya kerusakan jaringan pada bagian abdomen pasca tindakan operasi laparatomi. Mekanisme nyeri dimulai dengan adanya kerusakan jaringan yang terus berkembang akan memicu pelepasan zat-zat kimia seperti prostaglandin E, bradikinin, serotinin dan histamin. Zat kima tersebut akan merangsang reseptor nyeri dan mentransmisikan medula spinalis dan selanjutnya menuju talamus, kemudian di kortek serebri nyeri tersebut dipersepsikan (Petel, 2010).

Dalam mengatasi nyeri pada Tn.S, intervensi keperawatan yang dilakukan adalah pain management yang mengacu pada NIC. Dengan melakukan intervensi pain management diharapkan Tn.S dapat mengontrol nyeri pada skala 4 dengan kriteria hasil mampu mengenal penyebab nyeri, gejala nyeri yang dirasakan dan waktu timbulnya nyeri, tanda vital dalam batas normal, mampu menggunakan terapi farmakologi serta non farmakologi dan melaporkan terjadinya penurunan skala nyeri (Butcher et al., 2018).

Manajemen nyeri yang baik setelah operasi menurut program Enhanced Recovery After Surgery (ERAS) dianjurkan agar pasien dapat melakukan mobilisasi sesegera mungkin, menurunkan resiko komplikasi, 
memperpendek lama rawat dan mengurangi terjadinya angka kematian. Penatalaksanaan manajemen nyeri yang tidak adekuat dapat menyebabkan lamanya proses penyembuhan luka, tromboemboli vena dan infeksi sistemik (Scott, Nygren, \& Francis, 2019). Hal ini tentu juga pada kasus pasien pasca pembedahan laparatomi.

Manajemen untuk mengurangi rasa nyeri dapat menggunakan metode farmakologi dan non farmakologi. Kolaborasi dalam pemberian analgesik umum diberikan sejak pasien pasien menyelesaikan tindakan operasi. Perawat memiliki peran untuk mengkaji nyeri secara komprehensif dan memantau efektivitas pemberian terapi analgetik. Pengunaan obat-obatan analgetik yang diberikan berasal dari golongan opoid untuk nyeri dengan skala tinggi dan dan golongan non opid untuk rasa nyeri ringan hingga sedang.

Terapi komplementer dapat diberikan untuk mengurangi nyeri tanpa mengganggu terapi lainnya. Terapi musik salah satu jenis terapi komplementer yang banyak digunakan untuk menangani masalah nyeri. Terapi musik bertujuan untuk menenangkan pasien secara emosional sehingga sekresi adrenalin akan terhambat dan sebaliknya sekresi kortisol akan meningkat sehingga efek nyeri menjadi berkurang. Pemberian terapi musik juga dapat mempengaruhi hormon stres dan meningkatkan aktivitas dopamin pada mesolimbik otak (Singh \& Chaturvedi, 2015). Terapi musik merupakan intervensi non farmakologi yang aman, mudah dilakukan dalam praktik keperawatan.

Pemberian terapi musik merupakan bentuk dari rangsang yang diterima oleh indera pendengaran yang mempengaruhi kebutuhan secara fisik, psikologi, keognitif, sosial dan spiritual pendengarnya (Lindquist, Ruth; Tracy, Mary Fran; Snyder, 2018 ; Sykes, Nigel; Michael Bennet, 2008). Musik memiliki berbagai faktor yang mampu mengaktifkan otak secara bilateral didalam ritme, melodi, harmoni, timbre, akord serta dinamika musik (Singh \& Chaturvedi, 2015).

Pemberian terapi musik pada beberapa penelitian menunjukkan memiliki efektifitas untuk menurukan intensitas dan nyeri. Penelitian tentang pemberian terapi musik pada kasus pasien pasca operasi abdomen memiliki hasil penggunaan menurunkan intensitas dan distress nyeri pada hari kedua (Vaajoki, Pietilä, Kankkunen, \& Vehviläinen-Julkunen, 2013).

Tn.S setelah diberikan kombinasi terapi farmakologi dan non farmakologi berupa terapi musik sebanyak empat kali selama 2 hari terdapat penurunan skala nyeri secara bertahap. Penurunan skala nyeri pada pasien Tn.S dirasakan mulai pada pemberian terapi musik dipertemuan kedua. Pada pertemuan pertama setelah diberikan terapi musik memiliki skala nyeri Tn.S berdasarkan NRS bernilai 6, pemberian terapi belum menunjukkan terjadinya penurunan skala nyeri karena pasien belum dapat memfokuskan dirinya pada terapi musik yang diberikan. Penelitian yaitu dalam pemberian terapi musik dapat menurunkan tingkat nyeri di hari kedua pada pasien pasca pasien operasi abdomen. Saat dilakukan evaluasi sesi ke 4, diketahui jika skala nyeri Tn.S berada pada nilai NRS 3 .

Hasil pemberian intervensi berdasarkan teori comfort dari Katherine Kolbaca diketahui jika terapi non farmakologi berupa terapi musik dapat menurunkan rasa nyeri pada kasus kanker kolon pasca operasi laparatomi. Penggunaan terapi musik mendukung efektifitas terapi farmakologi dan mudah dilakukan dalam manajemen nyeri sehingga kenyamanan didapatkan oleh pasien.

\section{Simpulan}

Perawat penting untuk melakukan pengkajian nyeri pasca tindakan operasi laparatomi. Pengkajian nyeri yang efektif harus dilakukan secara komprehensif untuk menentukan intervensi yang perlu dilakukan. Penggunaan terapi non farmakologis dapat digunakan sebagai terapi tambahan atau pendamping dari pemberian terapi farmakologis. Dalam beberapa penelitian, penggunaan terapi musik diketahui memiliki efek bukan hanya untuk menurunkan tingkat nyeri tetapi juga menurunkan distresss pasien 
pasca tindakan operasi. Penggunaan terapi musik merupakan bagian dari asuhan keperawatan.

\section{Referensi}

Black, J. M \& Hawk, J. H (2014). Keperawatan medikal bedah, manajemen klinis untuk hasil yang diharapkan. Edisi 8. Buku 2. Singapore Pte Ltd: Elsevier

Butcher, H. K., Bulechek, G. M., Dochterman, J. M., \& Wagner, C. M. (2018). Nursing Interventions Classification ( NIC) (Seventh Ed). Elsevier Inc.

Dueñas, M., Ojeda, B., Salazar, A., Mico, J. A., \& Failde2, I. (2016). A review of chronic pain impact on patients, their social environment and the health care system. Journal of pain research, (9), 457-467.

https://doi.org/https://doi.org/10.2147/ JPR.S105892

Kuipers, E. J., Grady, W. M., Lieberman, D., Seufferlein, T., Sung, J. J., Boelens, P. G., ... Watanabe, T. (2015). Colorectal cancer. Nature Publishing Group, https://doi.org/10.1038/nrdp.2015.65

Lindquist, Ruth; Tracy, Mary Fran; Snyder, M. (2018). Complementary and Alternative Therapies in Nursing (Eighth edi). New York, NY: Springer Publishing Company.

Rawla, P., Sunkara, T., \& Barsouk, A. (2019). Epidemiology of colorectal cancer: incidence, mortality , survival , and risk factors. Gastroenterology Rev, 14, 89-103. https://doi.org/DOI:

https://doi.org/10.5114/pg.2018.81072

Scott, U. O. G. M. J., Nygren, M. H. J., \& Francis, N. D. N. (2019). Guidelines for Perioperative Care in Elective Colorectal Surgery: Enhanced Recovery After Surgery ( ERAS) Society Recommendations: 2018. World Journal of Surgery, 43(3), 659-695.

https://doi.org/10.1007/s00268-018- 4844-y

Singh, P., \& Chaturvedi, A. (2015).

Complementary and Alternative

Medicine in Cancer Pain

Management: A Systematic Review.

21(1),

105-115.

https://doi.org/10.4103/0973-

1075.150202

Smith, M. C., \& Parker, M. E. (2015).

Nursing Theories \& Nursing Practice (Fourth Edi). Philadelphia,: F. A. Davis Company.

Swift, A. (2018). Understanding the effect of pain and how the human body responds. NurisingTimes, 22-26.

Sykes, Nigel; Michael Bennet, C. Y. (2008). Clinical Pain Management: Cancer Pain 2nd edition (2nd editio; A. S. Rice, ed.). Hodder Arnold.

Treede, R. (2018). The International Association for the Study of Pain definition of pain : as valid in 2018 as in 1979 , but in need of regularly updated footnotes. Pain reports, 3, 35.

https://doi.org/doi:10.1097/PR9.0000 000000000643

Vaajoki, A., Pietilä, A. M., Kankkunen, P., \& Vehviläinen-Julkunen, K. (2013). Music intervention study in abdominal surgery patients: Challenges of an intervention study in clinical practice. International Journal of Nursing Practice, 19(2), 206-213.

https://doi.org/10.1111/ijn.12052 